\title{
Age-Dependent Heavy Metal Content in Muscle Tissue of Brown Bullhead (Ictalurus nebulosus, Le Suerur, 1819)
}

\section{Przemyslaw Pokorny*, Wojciech Dobicki, Kamila Tarbaj, Monika Kowalska-Góralska, Ryszard Polechoński, Magdalena Senze}

\author{
Department of Hydrobiology and Aquaculture, Wrocław University of Environmental and Life Science, \\ Chełmońskiego 38C, 51-630 Wroclaw, Poland \\ Received: January 30, 2015 \\ Accepted: March 5, 2015
}

\begin{abstract}
We used brown bullheads (Ictalurus nebulosus) from Milicz Ponds in our study. The authors examined the impacts of age, body length, body weight, and the condition of the fish on concentrations of metals $(\mathrm{Cd}$, $\mathrm{Pb}, \mathrm{Ni}, \mathrm{Cu}$, and $\mathrm{Zn})$ in their muscle tissue $(\mathrm{n}=62)$. The metal contents in muscle tissue increased in the order from $\mathrm{Cd}<\mathrm{Ni}<\mathrm{Pb}<\mathrm{Cu}<\mathrm{Zn}$ and amounted to $0.0177,0.0754,0.1121,0.1979,4.7358 \mathrm{mg} / \mathrm{kg}$ of wet weight respectively. Also, the bioconcentration factors $(\mathrm{BCF})$ were calculated based on the metal contents in muscle tissue, water and bottom sediment.

The obtained results allow us to conclude that the metal concentrations in muscle tissue decrease with age (for $\mathrm{Pb}$ and $\mathrm{Zn}$, the correlation is highly statistically significant, with the $\mathrm{p}$ value $\leq 0.01$ ). A relationship between body length and weight and $\mathrm{Zn}$ content $(\mathrm{p} \leq 0.01$ ) was confirmed, as well as between the condition of the fish (expressed by Fulton's condition factor) and $\mathrm{Cd}$ and $\mathrm{Cu}$ concentrations $(\mathrm{p} \leq 0.05)$.
\end{abstract}

Keywords: age, heavy metals, bioconcentration, brown bullhead

\section{Introduction}

Metal concentrations in fish tissues have most often been investigated in commercial fish species that are important in economic terms. Other species have been examined only occasionally. The brown bullhead, Ictalurus nebulosus, is native to North America and it is an alien and invasive species among Polish fish fauna [1].

In recent years we have observed an expansion of this species in Polish waters. A large population of brown bullhead has been present in the Milicz Ponds area, a nearly 10-century-old group of carp ponds protected under the Ramsar Convention on Wetlands and Living Lakes Global Nature Fund, as well as being included in the European Natura 2000 Network [2].

*e-mail: przemyslaw.pokorny@up.wroc.pl
According to Polish law, it is forbidden to introduce brown bullheads into unenclosed waters (also after capture) $[3,4]$. This positively contributes to the use of this species as an indicator in environmental pollution testing [5].

The brown bullhead's muscle tissue was investigated for contents of the heavy metals $\mathrm{Cd}, \mathrm{Hg}, \mathrm{Ni}, \mathrm{Cu}$, and $\mathrm{Zn}$, and the determination of the bioconcentration factor (BCF); however, researchers have usually failed to consider the age of the fish. These elements play various roles: $\mathrm{Hg}$ and $\mathrm{Cd}$ are toxic even in small concentrations (their indispensability in living organisms has not been confirmed); $\mathrm{Cu}$ and $\mathrm{Zn}$ are essential for living organisms' vital functions, but they are toxic at high concentrations; and Ni has a non-established status, although it has been identified (as have $\mathrm{Cd}$ and $\mathrm{Pb}$ ) as a priority substance in water environment by the European Union $[6,7]$. 
The metal concentrations in fish tissues depend on numerous parameters, including metal content in water and food, and on environmental parameters. Many authors have demonstrated the relationship between the metal contents in tissues and fish age and size (body length, weight) [5, 8-12].

The aim of this paper was to determine the relationship between the metal concentration in the muscle tissue of the brown bullhead and their age and size (body length, body weight, Fulton's condition factor). At the same time, an attempt was made to determine the relationship between concentrations of specific metals.

\section{Materials and Methods}

Brown bullheads were obtained from Bolko Pond, a component of Stawno Fishing Farm in the Milicz Ponds area during the commercial autumn capture of carp. A total of 62 fish were acquired, which were later measured and weighed, their ages were determined on the basis of vertebrate growth rings $[13,14]$, and their muscle tissue was collected for further investigation.

During the summer production season, water and bottom sediment samples were collected from the pond. Select water parameters were analysed: alkalinity, total hardness, electrolytic conductivity, $\mathrm{pH}$, dry residue, dissolved substance, and suspension. Next, water samples were thickened by adding $\mathrm{HNO}_{3}$. Sediment samples were air-dried and subjected to wet mineralisation using mixed nitric acid $\left(\mathrm{HNO}_{3}\right)$ and perchloric acid $\left(\mathrm{HClO}_{4}\right)(3: 1)$ in a Mars 5 microwave digestion system (CEM Corporation, USA).

The muscle tissue was subjected to wet mineralisation using nitric acid $\left(\mathrm{HNO}_{3}\right)$ in a Mars 5 microwave digestion system (CEM Corporation, USA).

In the obtained mineralisation (of water, sediments, muscle tissue), $\mathrm{Cd}, \mathrm{Pb}, \mathrm{Ni}, \mathrm{Cu}$, and $\mathrm{Zn}$ concentrations were determined using an atomic absorption spectrophotometer (SpectrAA FS220, Varian, Australia).

The results of the analyses were verified using the certified reference material DORM-3 (fish protein from the National Research Council Canada).

The concentrations of the examined elements in the water were given in $\mathrm{mg} \cdot \mathrm{dm}^{-3}$, in the sediment in $\mathrm{mg} \cdot \mathrm{kg}^{-1}$ of dry weight, and in muscles in $\mathrm{mg} \cdot \mathrm{kg}^{-1}$ of wet weight; fish weight was given in $\mathrm{g}$ and length in $\mathrm{cm}$.

Based on the obtained fish measurements, Fulton's condition factor $(\mathrm{K})$ was calculated.

$$
F=\frac{W \times 100}{T L^{3}}
$$

...where $W$ means the fish weight (in g), and $T L$ is total length (in $\mathrm{cm}$ ) [15].

Bioconcentration factors were calculated using the formula:

$$
B C F_{e}=\frac{C_{f}}{C_{e}}
$$

...where $C_{f}$ means the metal content in muscle tissue (mg. $\mathrm{kg}^{-1}$ ) and $C_{e}$ means the metal concentration in the environment (water in $\mathrm{mg} \cdot \mathrm{dm}^{-3}$ or bottom sediment in $\mathrm{mg} \cdot \mathrm{kg}^{-1}$ ) $[6,16]$.

The coefficient of variation $(V)$ was calculated using the formula:

$$
V=\frac{S D}{x} \times 100 \%
$$

...where $S D$ is the standard deviation, and $x$ the arithmetic mean.

Metal pollution index (MPI) was calculated using the formula:

$$
M P I=\left(C_{f 1} \times C_{f 2} \ldots C_{f n}\right)^{1 / n}
$$

...where $C_{f i}$ is concentration for metal $i$ in the sample [17].

Statistical calculations were performed using Statistica 10.0 (StatSoft).

Significant differences in metal concentrations across specific age groups were determined based on the KruskalWallis one-way analysis of variance (ANOVA), and relationships between determined parameters were determined based on Spearman's rank correlation coefficient.

\section{Results}

Water and bottom sediment samples were collected from the pond in summer. The results of physical and chemical investigations can be typical for water of carp ponds in our climate zone (Table 1). The metal content of water and bottom sediments are summarized in Table 2 .

The ages of the examined fish were determined to range from 1-4 years (average of 2.7 years). The mean body length was $22 \mathrm{~cm}(8.5-30.5 \mathrm{~cm})$, mean body weight $141.5 \mathrm{~g}$ (6.2-378.8 g). Fulton's condition factor $(\mathrm{K})$ ranged from 0.89 to 1.44 and its mean value was 1.13 (Table 3 ).

Table 1. Some physical and chemical parameters of fishpond water in summer.

\begin{tabular}{|l|c|c|}
\hline \multicolumn{1}{|c|}{ Parameter } & Unit & Value \\
\cline { 1 - 1 } Alkalinity & \multirow{2}{*}{$\mathrm{mg} \mathrm{CaCO}_{3} \cdot \mathrm{dm}^{-3}$} & 80.82 \\
\cline { 1 - 1 } Total hardness & & 135.66 \\
\hline Electrolytic conductivity & $\mu \mathrm{S} \cdot \mathrm{cm}^{-1}$ & 360 \\
\hline $\mathrm{pH}$ & - & 7.63 \\
\hline Dry residue & \multirow{2}{*}{$\mathrm{mg} \cdot \mathrm{dm}^{-3}$} & 247 \\
\cline { 1 - 1 } Dissolved substance & & 198 \\
\cline { 1 - 1 } Suspension & & 49 \\
\cline { 1 - 1 } & &
\end{tabular}


Table 2. Metal concentrations in fishpond water $\left(\mathrm{mg} \cdot \mathrm{dm}^{-3}\right)$ and bottom sediment $\left(\mathrm{mg} \cdot \mathrm{kg}^{-1}\right.$ dry weight $)$ in summer.

\begin{tabular}{|c|c|c|c|c|c|c|c|}
\hline \multirow{2}{*}{ Material } & \multirow{2}{*}{ Unit } & \multicolumn{6}{|c|}{ Metal concentration } \\
\hline & & $\mathrm{Cd}$ & $\mathrm{Pb}$ & $\mathrm{Ni}$ & $\mathrm{Cu}$ & $\mathrm{Zn}$ & MPI \\
\hline Water & $\mathrm{mg} \mathrm{dm} \mathrm{m}^{-3}$ & 0.0007 & 0.0038 & 0.0273 & 0.0077 & 0.0336 & 0.0072 \\
\hline Bottom sediment & mg.kg-1 (d.wt.) & 0.519 & 5.391 & 2.565 & 0.597 & 4.875 & 1.836 \\
\hline
\end{tabular}

MPI - metal pollution index

Table 3. Fish age, length, weight, Fulton's condition factor $(\mathrm{K})$, and the mean, standard deviation, ranges of concentration, and variability of investigated elements.

\begin{tabular}{|c|c|c|c|c|c|c|c|c|c|c|}
\hline & \multirow{2}{*}{$\begin{array}{l}\text { Age } \\
\text { (year) }\end{array}$} & \multirow{2}{*}{$\begin{array}{l}\text { Length } \\
(\mathrm{cm})\end{array}$} & \multirow{2}{*}{$\begin{array}{l}\text { Weight } \\
(\mathrm{g})\end{array}$} & \multirow{2}{*}{ K } & \multicolumn{6}{|c|}{ Metal concentration (mg.kg-1 w.wt) } \\
\hline & & & & & $\mathrm{Cd}$ & $\mathrm{Pb}$ & $\mathrm{Ni}$ & $\mathrm{Cu}$ & $\mathrm{Zn}$ & MPI \\
\hline Mean & 2.68 & 22.05 & 141.47 & 1.1266 & 0.0177 & 0.1121 & 0.0754 & 0.1979 & 4.7358 & 0.1254 \\
\hline SD & 0.86 & 5.12 & 84.13 & 0.1127 & 0.0115 & 0.0395 & 0.1357 & 0.1387 & 1.2209 & 0.0785 \\
\hline Min & 1 & 8.50 & 6.20 & 0.8893 & 0.0005 & 0.0628 & 0.0020 & 0.0030 & 3.1525 & 0.0248 \\
\hline Max & 4 & 30.50 & 378.80 & 1.4399 & 0.0547 & 0.3394 & 0.7824 & 0.5996 & 9.2744 & 0.3730 \\
\hline $\mathrm{V}$ & 32.01 & 23.20 & 59.47 & 10.00 & 65.28 & 35.24 & 180.05 & 70.11 & 25.78 & 62.60 \\
\hline
\end{tabular}

SD - standard deviation, V - coefficient of variability (\%), MPI - metal pollution index, K - Fulton's condition factor

Table 4. Metal concentrations in muscle of brown bullhead as dependence on age $\left(\mathrm{mg} \cdot \mathrm{kg}^{-1} \mathrm{w} . \mathrm{wt}\right)$.

\begin{tabular}{|c|c|c|c|c|c|}
\hline \multirow{2}{*}{ Metal } & & \multicolumn{4}{|c|}{ Age } \\
\hline & & $1(\mathrm{n}=5)$ & $2(\mathrm{n}=21)$ & $3(n=24)$ & $4(n=11)$ \\
\hline \multirow{3}{*}{$\mathrm{Cd}$} & Mean \pm SD & $0.0435^{\mathrm{Aa}} \pm 0.0095$ & $0.0125^{\mathrm{Bb}} \pm 0.0086$ & $0.0174^{\mathrm{ABb}} \pm 0.0091$ & $0.0173^{\mathrm{ABab}} \pm 0.0074$ \\
\hline & Range & $0.0287-0.0547$ & $0.0005-0.0322$ & $0.0050-0.0322$ & $0.0022-0.0292$ \\
\hline & V & 21.9303 & 68.9765 & 51.9993 & 42.6042 \\
\hline \multirow{3}{*}{$\mathrm{Pb}$} & Mean \pm SD & $0.2001^{\mathrm{Aa}} \pm 0.0825$ & $0.1105^{\mathrm{ABb}} \pm 0.0221$ & $0.1000^{\mathrm{Bb}} \pm 0.0221$ & $0.1024^{\mathrm{Bb}} \pm 0.0245$ \\
\hline & Range & $0.1370-0.3394$ & $0.0818-0.1738$ & $0.0628-0.1488$ & $0.0656-0.1460$ \\
\hline & V & 41.2112 & 20.0319 & 22.1344 & 23.9152 \\
\hline \multirow{3}{*}{$\mathrm{Ni}$} & Mean \pm SD & $0.0926 \pm 0.0960$ & $0.0560 \pm 0.0854$ & $0.0598 \pm 0.1215$ & $0.1383 \pm 0.2376$ \\
\hline & Range & $0.0020-0.2443$ & $0.0020-0.2751$ & $0.0020-0.4408$ & $0.0020-0.7824$ \\
\hline & V & 103.7168 & 152.4550 & 203.1447 & 171.8018 \\
\hline \multirow{3}{*}{$\mathrm{Cu}$} & Mean \pm SD & $0.3646 \pm 0.1875$ & $0.1764 \pm 0.1312$ & $0.1852 \pm 0.1286$ & $0.1991 \pm 0.1308$ \\
\hline & Range & $0.1007-0.5996$ & $0.0030-0.5162$ & $0.0030-0.4066$ & $0.0160-0.5085$ \\
\hline & $\mathrm{V}$ & 51.4268 & 74.4025 & 69.4433 & 65.7037 \\
\hline \multirow{3}{*}{$\mathrm{Zn}$} & Mean \pm SD & $7.6197^{\mathrm{A}} \pm 0.6878$ & $4.7834^{\mathrm{AB}} \pm 1.1570$ & $4.3107^{\mathrm{B}} \pm 0.5514$ & $4.3248^{\mathrm{B}} \pm 0.9932$ \\
\hline & Range & $6.5902-8.4450$ & $3.6651-9.2744$ & $3.5870-5.4654$ & $3.1525-6.9712$ \\
\hline & V & 9.0260 & 24.1870 & 12.7922 & 22.9655 \\
\hline \multirow{3}{*}{ MPI } & Mean \pm SD & $0.3344^{\mathrm{a}} \pm 0.2068$ & $0.1045^{b} \pm 0.06248$ & $0.1144^{\mathrm{b}} \pm 0.0718$ & $0.1299^{a b} \pm 0.0626$ \\
\hline & Range & $0.1114-0.7201$ & $0.0551-0.2693$ & $0.0248-0.2724$ & $0.0403-0.2660$ \\
\hline & V & 61.8266 & 59.7552 & 62.7387 & 48.2079 \\
\hline
\end{tabular}

Different letters (vertical) indicated statistically significant differences: ${ }^{A B}-p \leq 0.01,{ }^{a b}-p \leq 0.05$;

$\mathrm{SD}$ - standard deviation; $\mathrm{V}$ - coefficient of variability (\%), MPI - metal pollution index 
Table 5. The factors of select metals bioconcentration from water $\left(\mathrm{BCF}_{\mathrm{w}}\right)$ to the muscle of brown bullhead as dependent on age.

\begin{tabular}{|c|c|c|c|c|c|}
\hline \multirow{2}{*}{ Metal } & & \multicolumn{4}{|c|}{ Age } \\
\cline { 3 - 6 } & & $1(\mathrm{n}=5)$ & $2(\mathrm{n}=21)$ & $3(\mathrm{n}=24)$ & $4(\mathrm{n}=11)$ \\
\hline \multirow{2}{*}{$\mathrm{Cd}$} & Mean $\pm \mathrm{SD}$ & $62.20 \pm 13.64$ & $17.83 \pm 12.30$ & $24.89 \pm 12.94$ & $24.66 \pm 10.51$ \\
\cline { 2 - 6 } & Range & $41.00-78.14$ & $0.71-46.00$ & $7.14-46.00$ & $3.14-41.71$ \\
\hline \multirow{2}{*}{$\mathrm{Pb}$} & Mean $\pm \mathrm{SD}$ & $52.67 \pm 21.70$ & $29.07 \pm 5.82$ & $26.32 \pm 5.83$ & $26.94 \pm 6.44$ \\
\cline { 2 - 6 } & Range & $36.04-89.30$ & $21.52-45.73$ & $16.52-39.17$ & $17.27-38.43$ \\
\hline \multirow{2}{*}{$\mathrm{Ni}$} & Mean $\pm \mathrm{SD}$ & $3.39 \pm 3.52$ & $2.05 \pm 3.13$ & $2.19 \pm 4.45$ & $5.07 \pm 8.70$ \\
\cline { 2 - 6 } & Range & $0.07-8.95$ & $0.07-10.08$ & $0.07-16.15$ & $0.07-28.66$ \\
\hline \multirow{2}{*}{$\mathrm{Cu}$} & Mean $\pm \mathrm{SD}$ & $47.35 \pm 24.35$ & $22.90 \pm 17.04$ & $24.06 \pm 16.71$ & $25.86 \pm 16.99$ \\
\cline { 2 - 6 } & Range & $13.08-77.87$ & $0.39-67.04$ & $0.39-52.81$ & $2.08-66.04$ \\
\cline { 2 - 6 } & Mean $\pm \mathrm{SD}$ & $226.78 \pm 20.47$ & $142.36 \pm 34.43$ & $128.29 \pm 16.41$ & $128.71 \pm 29.56$ \\
\hline
\end{tabular}

$\mathrm{SD}$ - standard deviation

Table 6. The factors of select metals bioconcentrations from bottom sediment $\left(\mathrm{BCF}_{\mathrm{s}}\right)$ to the muscle of brown bullhead as dependent on age.

\begin{tabular}{|c|c|c|c|c|c|}
\hline \multirow{2}{*}{ Metal } & & \multicolumn{4}{|c|}{ Age } \\
\cline { 3 - 6 } & & $1(\mathrm{n}=5)$ & $2(\mathrm{n}=21)$ & $3(\mathrm{n}=24)$ & $4(\mathrm{n}=11)$ \\
\hline \multirow{3}{*}{$\mathrm{Cd}$} & Mean $\pm \mathrm{SD}$ & $0.0839 \pm 0.0184$ & $0.0240 \pm 0.0166$ & $0.0336 \pm 0.0175$ & $0.0333 \pm 0.0142$ \\
\cline { 2 - 6 } & Range & $0.0553-0.1054$ & $0.0010-0.0620$ & $0.0096-0.0620$ & $0.0042-0.0563$ \\
\hline \multirow{2}{*}{$\mathrm{Pb}$} & Mean $\pm \mathrm{SD}$ & $0.0371 \pm 0.0153$ & $0.0205 \pm 0.0041$ & $0.0186 \pm 0.0041$ & $0.0190 \pm 0.0045$ \\
\cline { 2 - 6 } & Range & $0.0254-0.0629$ & $0.0152-0.0322$ & $0.0116-0.0276$ & $0.0122-0.0271$ \\
\hline \multirow{2}{*}{$\mathrm{Ni}$} & Mean $\pm \mathrm{SD}$ & $0.0361 \pm 0.0374$ & $0.0218 \pm 0.0333$ & $0.0233 \pm 0.0474$ & $0.0539 \pm 0.0926$ \\
\cline { 2 - 6 } & Range & $0.0008-0.0952$ & $0.0008-0.1073$ & $0.0008-0.1719$ & $0.0008-0.3050$ \\
\cline { 2 - 6 } & Mean $\pm \mathrm{SD}$ & $0.6107 \pm 0.3141$ & $0.2954 \pm 0.2198$ & $0.3103 \pm 0.2155$ & $0.3335 \pm 0.2191$ \\
\hline \multirow{2}{*}{$\mathrm{Zn}$} & Range & $0.1687-1.0044$ & $0.0050-0.8647$ & $0.0050-0.6811$ & $0.0268-0.8518$ \\
\cline { 2 - 6 } & Mean $\pm \mathrm{SD}$ & $1.5630 \pm 0.1411$ & $0.9812 \pm 0.2373$ & $0.8842 \pm 0.1131$ & $0.8871 \pm 0.2037$ \\
\hline
\end{tabular}

$\mathrm{SD}$ - standard deviation

The obtained results (Tables 2, 3) allowed putting the examined elements in order from the lowest to highest concentration.

$$
\begin{array}{ll}
\text { Water: } & \mathrm{Cd}<\mathrm{Pb}<\mathrm{Cu}<\mathrm{Ni}<\mathrm{Zn} \\
\text { Sediment: } & \mathrm{Cd}<\mathrm{Cu}<\mathrm{Ni}<\mathrm{Zn}<\mathrm{Pb} \\
\text { Muscle: } & \mathrm{Cd}<\mathrm{Ni}<\mathrm{Pb}<\mathrm{Cu}<\mathrm{Zn}
\end{array}
$$

The highest metal concentration (except for Ni) was found in muscle tissue of the youngest fish (1 year-old). The lowest metal concentrations were observed in 2- $(\mathrm{Cd}$, $\mathrm{Ni}, \mathrm{Cu}$ ) or 3-year-old fish (Pb, Zn) (Table 4). Significant differences in muscle tissue metal concentrations $(\mathrm{Cd}, \mathrm{Pb}$, $\mathrm{Zn}$, and MPI) at different ages were statistically confirmed.

Irrespective of a fish's age, Cd muscle tissue concentration was the lowest, and $\mathrm{Zn}$ concentration was the highest. In 1-3-year old fish, metals ordered according to growing concentrations, formed a rank identical to the rank with no division into age groups. In the fourth year, $\mathrm{Ni}$ switched with $\mathrm{Pb}(\mathrm{Cd}<\mathrm{Pb}<\mathrm{Ni}<\mathrm{Cu}<\mathrm{Zn})$. This was caused by considerable growth of $\mathrm{Ni}$ concentration (more than double the growth in relation to the third year).

Based on the metal content in brown bullhead muscle tissue, in water, and in the sediment, the BCF were calculated. Respectively, $\mathrm{BCF}_{\mathrm{w}}$ for accumulation in relation to water concentration (Table 5) and $\mathrm{BCF}_{\mathrm{s}}$ in relation to metal concentration in sediments (Table 6).

Correlations between age, body length, body weight, Fulton's condition factor and metal content in the brown bullheads' muscle tissue were determined (Table 7). Correlations were different depending on the metal.

Correlations between concentrations of individual metals in the muscle tissue were also determined (Table 8). 
Table 7. Correlations between age, length, weight, Fulton's condition factor (K), and metal concentration in muscle of brown bullhead.

\begin{tabular}{|c|c|c|c|c|c|c|}
\hline \multirow{2}{*}{} & \multicolumn{6}{|c|}{ Spearman's correlation coefficient } \\
\cline { 2 - 7 } & $\mathrm{Cd}$ & $\mathrm{Pb}$ & $\mathrm{Ni}$ & $\mathrm{Cu}$ & Zn & MPI \\
\hline Age & 0.0140 & $-0.3418^{* *}$ & -0.0226 & -0.0771 & $-0.4381^{* *}$ & -0.0628 \\
\hline Length (cm) & -0.0079 & -0.2250 & 0.0156 & -0.0967 & $-0.3912^{* *}$ & -0.0192 \\
\hline Weight (g) & 0.0502 & -0.2152 & 0.0142 & -0.0453 & $-0.3918^{* *}$ & -0.0016 \\
\hline $\mathrm{K}$ & $0.2628^{*}$ & -0.0376 & -0.0127 & $0.2731^{*}$ & -0.0430 & 0.1179 \\
\hline
\end{tabular}

${ }^{*} \mathrm{p} \leq 0.05 ; * * \mathrm{p} \leq 0.01$

$\mathrm{K}$ - Fulton's condition factor; MPI - metal pollution index

Table 8. Correlations between concentrations of investigated metals.

\begin{tabular}{|c|c|c|c|c|}
\hline \multirow{2}{*}{} & \multicolumn{4}{|c|}{ Spearman's correlation coefficient } \\
\cline { 2 - 5 } & $\mathrm{Cd}$ & $\mathrm{Pb}$ & $\mathrm{Ni}$ & $\mathrm{Cu}$ \\
\hline $\mathrm{Pb}$ & 0.0890 & & & \\
\hline $\mathrm{Ni}$ & $0.2541^{*}$ & 0.0451 & & \\
\hline $\mathrm{Cu}$ & $0.6024^{*}$ & 0.2254 & $0.2725^{*}$ & \\
\hline $\mathrm{Zn}$ & -0.0122 & $0.6268^{*}$ & 0.1062 & $0.3246^{*}$ \\
\hline
\end{tabular}

${ }^{*} \mathrm{p} \leq 0.05$

\section{Discussion}

Metal concentrations in muscle tissue of fish reported in the literature differ significantly (Table 9).

Metal concentrations in the tissues of fish depend on the position of a given species in the trophic level [32-34]. And the highest metal concentrations have been reported in ground fish species. The brown bullhead is omnivorous; it mainly eats bottom-dwelling invertebrates, but it becomes a predator with age and may feed on smaller fish species. In general, it may be concluded that metals accumulate in muscle tissue in the following order: $\mathrm{Cd}<\mathrm{Pb}<\mathrm{Cu}<\mathrm{Zn}$ (according to increasing concentrations), which was confirmed herein. Ni concentration is usually lower or comparable to $\mathrm{Pb}$ concentration.

Metal concentrations were changing with the fish's age. Except for $\mathrm{Ni}$, metal concentrations in the muscle tissue of 4-year-old fish were lower than in the muscle tissue of 12-month-old fish. This difference ranged from $43 \%(\mathrm{Zn})$ to $60 \%(\mathrm{Cd})$, with statistically significance differences confirmed in the cases of $\mathrm{Pb}, \mathrm{Zn}(\mathrm{p} \leq 0.01)$, and $\mathrm{Cd}(\mathrm{p} \leq 0.05)$. These changes, however, were not identical in subsequent years. The largest fall in metal concentrations was observed between the first and second years of life and it concerned all examined elements. The differences ranged from $37 \%$ (Zn) to $71 \%(\mathrm{Cd})$. Statistically significance differences between metal content in muscle tissue of 1- and 2-year-old fish for $\mathrm{Cd}(\mathrm{p} \leq 0.01), \mathrm{Pb}$, and $\mathrm{Zn}(\mathrm{p} \leq 0.05)$ were confirmed. Also, between the first and second years, the concentrations of all metals expressed by MPI (by $69 \%, p \leq 0.05$ ) decreased statistically.
The correlations between age, body weight, body length, and Fulton's condition factor were low (Table 7). Relationships between $\mathrm{Cu}, \mathrm{Pb}$, and $\mathrm{Zn}$ concentrations and MPI, age, body weight, and body length were negative. Statistically significant negative correlations $(p \leq 0.01)$ between $\mathrm{Pb}$ and age, $\mathrm{Zn}$ and age, $\mathrm{Zn}$ and body length, and $\mathrm{Zn}$ and body weight were reported. Changes in metal concentration in muscle tissue were observed along with fish age and have been confirmed by many researchers $[9,20$, $25,38]$. However, the reported coefficients of correlations between metal content in the muscle tissue and the fish's age vary. Dobicki and Polechoński [9] also found negative correlations between $\mathrm{Pb}$ and age (pike perch, bream), and $\mathrm{Zn}$ and age (roach, bream), but at the same time they observed positive correlations between $\mathrm{Pb}$ and age in perch, and $\mathrm{Zn}$ and age in pike perch. In Nile tilapia, negative correlation between age and $\mathrm{Zn}$ was found [38]. Age-dependant changes in metal concentrations in the muscle tissue may be caused by differences in metabolism (faster in growing fish), defence mechanisms developed with age and detoxication ability, and changes in their position in the food chain (changes in the type of consumed food) $[9,20$, 39].

Negative correlation between $\mathrm{Zn}$ concentration and body length is reported, among others, in brown bullhead [23], perch [39], white sucker [23], bream [9, 25], and roach [9]. In pike perch $[9,21]$ and carp [30], on the other hand, positive correlation was observed. Similarly, in the case of the correlation between $\mathrm{Zn}$ and body weight, some authors have reported a negative correlation in bream, roach [9], and goldfish [30], whereas others have reported a positive correlation in pike perch $[9,21]$ and carp [30].

Correlations $(p \leq 0.05)$ between concentrations of the following metals: $\mathrm{Cd}-\mathrm{Ni}, \mathrm{Cd}-\mathrm{Cu}, \mathrm{Pb}-\mathrm{Zn}, \mathrm{Ni}-\mathrm{Cu}$, and $\mathrm{Cu}-\mathrm{Zn}$ were confirmed to be statistically significant. All correlations were positive. In the muscle tissue of various species, the following correlations were also reported: $\mathrm{Cd}-\mathrm{Ni}, \mathrm{Cd}-$ $\mathrm{Cu}$ [31], and $\mathrm{Pb}-\mathrm{Zn}$ [30]. But correlations between metal concentrations are species-specific and they depend on environmental parameters. One such parameter may be environmental pollution leading to increased metal concentration in the water. This may be confirmed by results of studies conducted on tilapias. They prove that in the case of fish exposed to metal pairs $(\mathrm{Cu}$ and $\mathrm{Cd}$ [40] as well as $\mathrm{Zn}$ and $\mathrm{Cd}[41]$ ), accumulation of each pair is lower than in the 
Table 9. Mean metal concentrations in fish muscle ( $\left.\mathrm{mg} \cdot \mathrm{kg}^{-1} \mathrm{w} . \mathrm{wt}.\right)$.

\begin{tabular}{|c|c|c|c|c|c|c|c|}
\hline \multirow{2}{*}{ Type of food } & \multirow{2}{*}{ Species } & \multicolumn{5}{|c|}{ Average metal concentration in fish muscle (mg. $\mathrm{kg}^{-1}$ w.wt.) } & \multirow{2}{*}{ Reference } \\
\hline & & $\mathrm{Cd}$ & $\mathrm{Pb}$ & $\mathrm{Ni}$ & $\mathrm{Cu}$ & $\mathrm{Zn}$ & \\
\hline \multirow{9}{*}{ Piscivorous } & \multirow{3}{*}{$\begin{array}{c}\text { Pike } \\
\text { Esox lucius }\end{array}$} & 0.0030 & 0.0200 & 0.0300 & 0.130 & 6.80 & {$[18]$} \\
\hline & & & & & 0.140 & 9.40 & [19] \\
\hline & & & & & 0.190 & 6.20 & \\
\hline & \multirow{2}{*}{$\begin{array}{c}\text { Pikeperch } \\
\text { Sander lucioperca }\end{array}$} & 0.0067 & 0.2761 & 0.2062 & 0.173 & 16.51 & {$[20]$} \\
\hline & & 0.0100 & & 0.1800 & 0.378 & 5.53 & {$[21]^{\mathrm{a}}$} \\
\hline & \multirow{4}{*}{$\begin{array}{c}\text { Perch } \\
\text { Perca fluviatilis }\end{array}$} & & 0.0600 & 0.0430 & 0.200 & 4.80 & \multirow{3}{*}[22]{$^{\mathrm{a}}$} \\
\hline & & & 0.0600 & 0.0360 & 0.940 & 2.70 & \\
\hline & & & 0.0740 & 0.0360 & 0.560 & 4.40 & \\
\hline & & 0.0030 & 0.0100 & 0.1300 & 0.160 & 5.20 & [18] \\
\hline \multirow{24}{*}{ Omnivorous } & & & 0.0480 & 0.0200 & 0.260 & 5.80 & \\
\hline & $\begin{array}{c}\text { Roach } \\
\text { Rutilus }\end{array}$ & & 0.1220 & 0.0360 & 0.580 & 2.80 & {$[22]^{\mathrm{a}}$} \\
\hline & & & 0.0820 & 0.0200 & 0.440 & 5.60 & \\
\hline & \multirow{3}{*}{$\begin{array}{l}\text { Brown bullhead } \\
\text { Ictalurus nebulosus }\end{array}$} & 0.0177 & 0.1121 & 0.0754 & 0.198 & 4.74 & this study \\
\hline & & 0.0060 & 0.1440 & 0.0800 & 0.240 & 6.00 & {$[23]^{\mathrm{a}}$} \\
\hline & & 0.0220 & 0.1380 & 0.1880 & 0.484 & 4.94 & {$[24]^{\mathrm{a}}$} \\
\hline & \multirow{6}{*}{$\begin{array}{c}\text { Bream } \\
\text { Abramis brama }\end{array}$} & 0.0114 & 0.3084 & 0.0869 & 1.332 & 17.58 & {$[20]$} \\
\hline & & 0.1220 & 0.3260 & & 0.444 & 2.90 & \multirow{2}{*}[25]{$^{\mathrm{a}}$} \\
\hline & & 0.0840 & 0.0880 & & 0.354 & 2.18 & \\
\hline & & 0.0020 & 0.0100 & 0.0500 & 0.170 & 2.80 & [18] \\
\hline & & & & & 0.180 & 3.20 & \\
\hline & & & & & 0.240 & 3.00 & \\
\hline & \multirow{9}{*}{$\begin{array}{l}\text { Common carp } \\
\text { Cyprinus carpio }\end{array}$} & 0.0800 & 0.0440 & & 0.517 & 4.60 & {$[26]$} \\
\hline & & & & & 0.530 & 4.98 & [27] \\
\hline & & 0.0759 & 0.1359 & 0.0393 & & & {$[28]$} \\
\hline & & 0.0042 & 0.0354 & & & 5.08 & {$[29]^{\mathrm{a}}$} \\
\hline & & 0.0160 & 0.0480 & 0.2800 & 0.514 & & {$[24]^{\mathrm{a}}$} \\
\hline & & 0.0010 & 0.0100 & 0.1000 & 0.080 & 3.30 & {$[18]$} \\
\hline & & 0.0129 & 0.0217 & & 1.130 & 9.34 & {$[30]$} \\
\hline & & 0.0580 & 1.2780 & 0.3000 & 0.994 & 5.71 & {$[31]^{\mathrm{a}}$} \\
\hline & & 0.0500 & 1.9900 & & 0.180 & 4.32 & {$[12]$} \\
\hline & \multirow{3}{*}{$\begin{array}{c}\text { Goldfish } \\
\text { Carassius auratus }\end{array}$} & 0.0026 & 0.0574 & & 0.378 & 26.00 & {$[29]^{\mathrm{a}}$} \\
\hline & & 0.0170 & 0.0849 & & 0.920 & 12.83 & {$[30]$} \\
\hline & & 0.1000 & 0.2900 & & 0.610 & 13.50 & {$[32]$} \\
\hline Herbivorous & $\begin{array}{c}\text { Grass carp } \\
\text { Ctenopharyngodon idella }\end{array}$ & 0.0834 & 0.2640 & 0.1340 & 0.118 & 0.38 & {$[33]^{\mathrm{a}}$} \\
\hline
\end{tabular}

a - in the original article in dry weight - recalculated on wet weight according formula w.wt. $=$ d.wt./5 [22] 
case of exposure to single metals. Moreover, this relationship is more discernible in the case of lower water metal concentrations. Furthermore, this phenomenon makes it more difficult to analyse the results of metal accumulation in the muscle tissue of fish.

The BCF value of metal concentration in muscle tissue, calculated in relation to metal concentration in water $\left(\mathrm{BCF}_{\mathrm{w}}\right)$ or sediment $\left(\mathrm{BCF}_{\mathrm{s}}\right)$, was changing along subsequent life years (Tables 5 and 6). The highest $\mathrm{BCF}_{\mathrm{w}}$ and $\mathrm{BCF}_{\mathrm{s}}$ values were reported for $\mathrm{Zn}$. The lowest $\mathrm{BCF}_{\mathrm{w}}$ value was reported for $\mathrm{Ni}$, and the lowest $\mathrm{BCF}_{\mathrm{s}}$ in 1-year-old fish for $\mathrm{Ni}$, whereas in older fish (2-4 years old) for $\mathrm{Pb}$. The literature offers scarce data for comparing the obtained $\mathrm{BCF}$ values. The $\mathrm{BCF}_{\mathrm{w}}$ for $\mathrm{Zn}$ reported for pike perch [39], pike, and bream [19] approximates the value obtained in our research. The $\mathrm{BCF}_{\mathrm{w}}$ for $\mathrm{Cu}$ reported for pike and bream [19], on the other hand, is 10-fold higher than that reported for the brown bullhead. These differences do not stem from different metal concentrations in the muscle tissue (lower metal concentration in lake water). The 10-fold higher $\mathrm{BCF}_{\mathrm{w}}$ value for $\mathrm{Cd}, \mathrm{Pb}, \mathrm{Ni}, \mathrm{Cu}$, and $\mathrm{Zn}$ in the muscle tissue of eight species from Taihu Lake was also reported by Tao et al. [42]. In this case, apart from significantly lower metal concentrations in water, their higher concentrations in muscle tissue were observed.

The calculated $\mathrm{BCF}_{\mathrm{s}}$ values approximate those reported for roach, perch pike, silver bream, and rudd [43]. Considerably lower $\mathrm{BCF}_{\mathrm{s}}$ values are reported for crucian [32].

However, the calculated BCF and values taken from literature suggest that the accumulation of metals in the muscle tissue of fish not only depends on their water or sediment concentrations, but also on their concentration in food.

Difficulties with confirming statistically significance differences between groups or correlations between analysed factors arose from differentiation of results within specific groups. This is confirmed by a high coefficient of variation $(\mathrm{V})$, which may be caused by individual idiosyncrasies (other than age, body length, body weight). The physiological condition of the fish was considered in the study during the calculation of Fulton's condition factor (K). Correlations between $\mathrm{Cu}$ and the condition factor, as well as $\mathrm{Cd}$ and the condition factor $(\mathrm{p} \leq 0.05)$, were statistically confirmed with both correlations being positive. Farkas et al. [25] confirmed correlations between the condition factor and $\mathrm{Hg}$ and $\mathrm{Zn}$ (negative), and $\mathrm{Pb}$ (negative in September and positive in May).

It appears, however, that this factor has a minor impact on the accumulation of metals in the muscle tissue of fish, as usually the relationship between the condition factor and the metal concentration or BCF in fish muscle tissue cannot be statistically confirmed.

\section{Conclusions}

1. Metal concentrations in brown bullhead muscle tissue change with age.
2. Negative correlations between $\mathrm{Pb}$ and $\mathrm{Zn}$ concentrations in the muscle tissue of brown bullhead and the fish's age, as well as between $\mathrm{Zn}$ concentration and body length and weight, were confirmed.

3. Positive correlations between $\mathrm{Cd}$ and $\mathrm{Cu}$ concentrations and the condition of the brown bullhead expressed via Fulton's condition factor were confirmed.

\section{Acknowledgements}

Publication supported by Wrocław Centre of Biotechnology, programme the Leading National Research Centre (KNOW) for years 2014-2018.

\section{References}

1. KOTUSZ J. Ameiurus nebulosus (Le Sueur, 1819). [In] Głowaciński Z., Okarma H., Pawłowski J., Solarz W., [Eds] Alien species in the fauna of Poland. I. An overview of the status. Institute of Nature Conservation, Polish Academy of Sciences, Kraków, 399-403, 2011 [In Polish].

2. KOWALSKA-GÓRALSKA M., ŁYSKOJĆ A. Fish production in ponds located in the region of Milicz in the years 1955-2005 [In] M. Krukowski, Drabiński A. [Eds] Nature Conservation in the Landscape Park "Dolina Baryczy." Wrocław University of Environmental and Life Sciences, Institute of Landscape Architecture. 37, 2009 [In Polish].

3. The water law, Journal of law No. 115, item 1229, 2001 [In Polish].

4. Regulation dated 9 September 2011 on the list of plants and animals of alien species, which if released to the natural environment can threaten native species or natural habitats. Journal of law No. 210, item 1260, 2011 [In Polish].

5. WEST D.W., LING N., HICKS B.J., TREMBLAY L.A., KIM N.D., VAN DEN HEUVEL M.R. Cumulative impacts assessment along a large river, using brown bullhead (Ameiurus nebulosus) populations. Environ. Toxicol. Chem. 7, (25), 1868, 2006.

6. JAKIMSKA A., KONIECZKA P., SKÓRA K., NAMIEŚNIK J. Bioaccumulation of metals in tissue of marine animals, Part I: The role and impact of heavy metals on organisms. Pol. J. Environ. Stud. 20, (5), 1117, 2011.

7. EUROPEAN PARLIAMENT AND OF THE COUNCIL. Directive 2008/105/EC on environmental quality standards in the field of water policy, amending and subsequently repealing Council Directives 82/176/EEC, 83/513/EEC, 84/156/EEC, 84/491/EEC, 86/280/EEC and amending Directive 2000/60/EC of the European Parliament and of the Council. Official Journal of the European Union, L 348/84, 2008.

8. JEZIERSKA B., WITESKA M. Metal toxicity to fish. Monografie Akademii Podlaskiej, Siedlce, 42, 2001.

9. DOBICKI W., POLECHOŃSKI R. Relationship between age and heavy metal bioaccumulation by tissues of four fish species inhabiting Wojnowskie Lakes. Acta Sci. Pol. Piscaria, 2, (1), 27, 2003.

10. ŁUCZYŃSKA J., BRUCKA-JASTRZĘBSKA E. Determination of heavy metals in the muscles of some Fish species from lakes of the North-Eastern Poland. Pol. J. Food Nutr. Sci. 15/56, (2), 141, 2006.

11. KRYWULT M., KLICH M., SZAREK-GWIAZDA E. Metal concentration in chub Leuciscus cephalus from a submontane river. Acta Ichtyol. Pisc. 38, (1), 47, 2008. 
12. ABDULRAHMAN N.M. Determination of some heavy metals levels in common carp fingerlings fed with yeast. Iraqi J. Vet. Sci. 27, (1), 61, 2013.

13. ALP A., KARA C., ÜÇKARDEŞ F., CAROL J., GARCÍABERTHOU E. Age and growth of the European catfish (Silurus glanis) in a Turkish Reservoir and comparison with introduced populations. Rev. Fish Biol. Fisher. 21, 283, 2011.

14. LEE W.-O., ZHANG M.-M., OH CH.-W., BAEK J.-M., SONG K.-J. Age and Growth of Barbel Steed Hemibarbus labeo in Goe-san Lake in Korea. Fish. Aquat. Sci. 15, (4), 353, 2012.

15. FROESE R. Cube law, condition factor and weight-lenght relationships: history, meta-analysis and recommendations. J. Appl. Ichthyol. 22, 241, 2006.

16. VAN DER OOST R., BEYER J., VERMEULEN N.P.E. Fish bioaccumulation and biomarkers in environmental risk assessment: a review. Environ. Toxicol. Phar. 13, 57, 2003.

17. USERO J., GONZALEZ-REGALADO E., GRACIA I. Trace metal in the bivalve mollusks Ruditapes decussates and Ruditapes philippinarum from the Atlantic coast of southern Spain. Environ. Int. 23, 291, 1997.

18. LIDWIN-KAŹMIERKIEWICZ M., POKORSKA K., PROTASOWICKI M., RAJKOWSKA M., WECHTEROWICZ Z. Content of selected essential and toxic metals in meat of freshwater fish from West Pomerania, Poland. Pol. J. Food Nutr. Sci. 59, (3), 219, 2009.

19. RAJKOWSKA M., PROTASOWICKI M. Distribution of metals ( $\mathrm{Fe}, \mathrm{Mn}, \mathrm{Zn}, \mathrm{Cu}$ ) in fish tissues in two lakes of different trophy in Northwestern Poland. Environ. Monit. Assess. 185, 3493, 2013.

20. POLECHOŃSKI R., DOBICKI W. Accumulation of heavy metals $(\mathrm{Pb}, \mathrm{Hg}, \mathrm{Cd}, \mathrm{Cr}, \mathrm{Ni}, \mathrm{Cu}, \mathrm{Zn})$ in fish tissues of predominant species in ichtiofauna from Wojnowskie Lakes. Pol. J. Environ. Stud. 11, (Suppl. 1), 5, 2001.

21. BAŞYIĞIT B., TEKIN-ÖZAN S. Concentrations of some heavy metals in water, sediment, and tissues of pikeperch (Sander lucioperca) from Karatas Lake releated to physicochemical parameters, fish size, and seasons. Pol. J. Environ. Stud. 22, (3), 633, 2013.

22. KUZNETSOVA A.I., ZARUBINA O.V., LEONOVA G.A. Comparison of $\mathrm{Zn}, \mathrm{Cu}, \mathrm{Pb}, \mathrm{Ni}, \mathrm{Cr}$, Sn, Mo concentrations in tissues of fish (roach and perch) from Lake Baikal and Bratsk reservoir, Russia. Environ. Geochem. Hlth. 24, 205, 2002.

23. HEIT M., KLUSEK C.S. Trace element concentrations in the dorsal muscle of white suckers and brown bullheads from two acidic Adirondack lakes. Water Air Soil Poll. 25, 87, 1985.

24. WEIS P., ASHLEY J.T.F. Contaminants in fish of the Hackensack Meadowlands, New Jersey: size, sex, and seasonal relationships as related to health risks. Arch. Environ. Con. Tox. 52, 80, 2007.

25. FARKAS A., SALÁNKI J., SPECZIÁR A. Age- and sizespecific patterns of heavy metals in the organs of freshwater fish Abramis brama L. populating a low-contaminated site. Water Res. 37, 959, 2003.

26. DOBICKI W., POLECHOŃSKI R., KOWALSKAGÓRALSKA M., POKORNY P. Bioaccumulation of trace metals in carp (Cyprinus carpio L.) organs. Zesz. Nauk. AR we Wrocławiu. 501, 57, 2004 [In Polish].

27. POKORNY P., DOBICKI W., POLECHOŃSKI R., SENZE M., KOWALSKA-GÓRALSKA M., SKRABUCHA A. Accumulation of chosen metals $(\mathrm{Cr}, \mathrm{Cu}, \mathrm{Zn})$ in elements of pond enviroment and in fish on the territory of agricultural drainage area. Chemistry for Agriculture. 7, 562, 2006.

28. POKORNY P., DOBICKI W., POLECHOŃSKI R., SENZE M., KOWALSKA-GÓRALSKA M. Bioaccumulation of $\mathrm{Cd}, \mathrm{Pb}$ and $\mathrm{Ni}$ in selected components of a pond environment. Chemistry for Agriculture. 8, 183, 2007.

29. QIAO-QIAO C., GUANG-WEI Z., LANGDON A. Bioaccumulation of heavy metals in fishes from Taihu Lake, China. J. Environ. Sci., 19, 1500, 2007.

30. LÜ C., HE J., FAN Q., XUE H. Accumulation of heavy metals in wild commercial fish from the Baotou Urban Section of the Yellow River, China. Environ. Earth Sci. 62, 679, 2011.

31. HOSSEINI ALHASHEMI A., SEKHAVATJOU M.S., HASSANZADEH KIABI B., KARBASSI A.R. Bioaccumulation of trace elements in water, sediment, and six fish species from a freshwater wetland, Iran. Microchem. J. 104, 1, 2012.

32. ZHUANG P., LI Z.-A., MCBRIDE M.B., ZOU B. WANG G. Health risk assessment for consumption of fish originating from ponds near Dabaoshan mine, South China. Environ. Sci. Pollut. Res. 20, 5844, 2013.

33. MALIK N., BISWAS A. K., QURESHI T. A., BORANA K., VIRHA R. Bioaccumulation of heavy metals in fish tissues of a freshwater lake of Bhopal. Environ. Monit. Assess. 160, 267, 2010.

34. POLECHOŃSKI R., DOBICKI W. Lead in chosen elements of the Lake Sława ecosystem. Limnol. Rev. 2, 313, 2002.

35. POLECHOŃSKI R., DOBICKI W., POKORNY P. Level of mercury tissues of pike-perch and bream from Wojnowskie Lakes in dependence of age. Zesz. Nauk. AR we Wrocławiu. 501, 265, 2004 [In Polish].

36. JAKIMSKA A., KONIECZKA P., SKÓRA K., NAMIEŚNIK J. Bioaccumulation of metals in tissue of marine animals, Part II: Metal concentrations in animal tissues. Pol. J. Environ. Stud. 20, (5), 1127, 2011.

37. HARDISSON A., RUBIO C., GUTIÉRREZ Á., JALILI A., HERNÁNDEZ-SÁNCHEZ C., LOZANO G., REVERT C., HERNÁNDEZ-ARMAS J. Total mercury in aquaculture fish. Pol. J. Environ. Stud. 21, (5), 1203, 2012.

38. RASHED M.N. Monitoring of environmental heavy metals in fish from Nasser Lake. Environ. Int. 27, 27, 2001.

39. STANEK M., STASIAK K., JANICKI B., BERNACKA H. Content of selected elements in the muscle tissue and gills of perch (Perca fluviatilis L.) and water from Polish lake. Pol. J. Environ. Stud. 21, (4), 1033, 2012.

40. PELGROM S.M.G.J., LAMERS L.P.M., LOCK R.A.C., BALM P.H.M., WENDELAAR BONGA S.E. Interactions between copper and cadmium modify metal organ distribution in mature tilapia, Oreochromis mossambicus. Environ. Pollut. 90, (3), 415, 1995.

41. FIRAT Ö., ÇOGUN H.Y., ASLANYAVRUSU S., KARGIN F. Antioxidant responses and metal accumulation in tissues of Nile tilapia Oreochromis niloticus under $\mathrm{Zn}, \mathrm{Cd}$ and $\mathrm{Zn}+$ Cd exposures. J. Appl. Toxicol. 29, 295, 2009.

42. TAO Y., YUAN Z., XIAONA H., WEI M. Distribution and bioaccumulation of heavy metals In aquatic organisms of different trophic levels and potential health risk assessment from Taihu lake, China. Ecotox. Environ. Safe. 81, 55, 2012.

43. SZAREK-GWIAZDA E., AMIROWICZ A. Bioaccumulation of trace elements in roach, silver bream, rudd, and perch living in an inundated opencast sulphur mine. Aquat. Ecol. 40, 221, 2006. 